\title{
RHIZOBACTERIAL PROMOTION OF EUCALYPT ROOTING AND GROWTH
}

\author{
Débora A. Teixeira ${ }^{1}$; Acelino Couto Alfenas ${ }^{1 *}$; Reginaldo Gonçalves Mafia ${ }^{1}$; Eraclides M. Ferreira ${ }^{1}$; \\ Leandro de Siqueira ${ }^{1}$; Luiz A. Maffia ${ }^{1}$; Ann H. Mounteer ${ }^{2}$
}

\begin{abstract}
${ }^{1}$ Department of Phytopathology, Federal University of Viçosa, Viçosa, Minas Gerais State, Brazil; ${ }^{2}$ Department of Civil and Environment Engineering, Federal University of Viçosa, Viçosa, Minas Gerais State, Brazil
\end{abstract}

Submitted: May 09, 2005; Returned to authors for corrections: March 09, 2006; Approved: October 13, 2006

\begin{abstract}
A total of 107 rhizobacterial isolates, obtained from the rhizosphere of eucalypt clones were tested as rooting inducers of cuttings and mini-cuttings planted in substrate composed of carbonized rice husk and vermiculite (1:1). Cuttings and mini-cuttings were planted in conical plastic tubes containing treated and untreated (control) substrate and kept under intermittent mist irrigation at $26-28^{\circ} \mathrm{C}$. After 35 days, rooting percentage and dry root matter of cuttings were evaluated. Ten isolates capable of providing gains of up to $110 \%$ in root formation and up to $250 \%$ in root biomass over non-inoculated control cuttings were selected. Gains in rooting varied according to clone and isolate tested. The greatest gains were obtained for the mini-cuttings exhibiting the lowest rooting efficiency. Among the ten isolates tested, only 3918 (code R98) and MF4 (code R87), produced 3-indole-acetic acid in vitro, at concentrations of 0.7 and $0.67 \mu \mathrm{g} \mathrm{ml}^{-1}$, respectively. Significant increases in rooting and root dry matter of cuttings grown on rhizobacteria-inoculated substrate were found when compared to untreated or indole-butyric acid (IBA) treated mini-cuttings.
\end{abstract}

Key words: Eucalyptus, cloning, mini-cutting, cutting, rhizobacteria

\section{INTRODUCTION}

Planted area of Eucalyptus spp. in Brazil is the second largest in the world, totaling about 3 million hectares. Brazilian eucalypt plantations are used to supply the increasing demand for solid wood and as raw material for pulp and charcoal (1). Largescale vegetative propagation from cuttings or mini-cuttings has been widely used. However, large variations in rooting between pure species and hybrid clones are often observed, and a gradual reduction in the rooting potential may occur with the ontogenetic aging of the mother plant. Therefore, alternative techniques that optimize rooting percentage of eucalypt cuttings and mini-cuttings will be useful for mass vegetative propagation. Plant Growth-Promoting Rhizobacteria (PGPR) can induce rooting, plant growth and disease control in many crops (19). Although the mechanisms are not completely clarified, plant growth promotion may occur by production of phytohormones such as auxins and gibberellins, by inhibition of ethylene synthesis and by mineralization of nutrients. In general, growth promotion depends on several mechanisms, and the main effects of PGPR are related to increases in root, stem and branch growth and, consequently, to increased plant yield. PGPR can also suppress deleterious or pathogenic microorganisms $(8,9,21)$ or stimulate the association of mycorrhizal fungi and Rhizobium sp. (21).

Although the effects of PGPR are well established for agricultural crops, little is known of their importance in forest species. The root growth promoting effect of rhizobacteria was reported for seedlings or micro-propagated plants belonging to the genera Pinus, Picea, Tsuga and Pseudotsuga $(6,11)$ and Eucalyptus (23). An increase of $44 \%$ in E. camaldulensis seedling biomass was observed after co-inoculation of the potting medium with Azotobacter chroococcum and Bacillus megaterium (23). However, to the best of our knowledge there are no references of rhizobacteria as rooting inducers of Eucalyptus spp. cuttings or mini-cuttings. Hence, the objective

*Corresponding Author. Mailing address: Universidade Federal de Viçosa - Centro de Ciências Agrárias, Departamento de Fitopatologia. 36570-000 Viçosa, MG - Brasil; Tel: (31) 3899-2939 ou (31) 3899-2240. E-mail: aalfenas@ufv.br 
of the present study was to isolate and select rhizobacterial isolates capable of inducing rooting of eucalypt cuttings and mini-cuttings. In vitro production of indole-acetic acid (IAA) by selected isolates was also evaluated.

\section{MATERIALAND METHODS}

\section{Isolation of rhizobacteria}

Rhizobacterial isolates were obtained from the rhizoplan of 35-40 day old Eucalyptus rooted cuttings. Root segments containing adhered substrate were placed in Erlenmeyer flasks containing $20 \mathrm{ml}$ distilled, sterilized water, sonicated $(40 \mathrm{kHz})$ (Sonicator® XL 2020) for $15 \mathrm{~min}$, and filtered through gauze. One fraction $(1 \mathrm{ml})$ of the filtrate was submitted to a dilution series of 1:10 up to $1 \times 10^{-5}$, and plated $(100 \mu \mathrm{l})$ on King's B medium (KMB) (SIGMA, MO, USA) (18). The other filtrate fraction $(10 \mathrm{ml})$ was distributed to sterilized test tubes and heated at $80^{\circ} \mathrm{C}$ for $20 \mathrm{~min}$ for selective isolation of Bacillus sp. Subsequently a dilution series was prepared as previously described, and the suspensions were plated on 523 medium (SIGMA, MO, USA) (16). Colonies varying in morphology were purified after incubation for $24-48 \mathrm{~h}$ at $28^{\circ} \mathrm{C}$, in the dark. Colonies grown on KMB were observed under UV light $(360 \mathrm{~nm})$ and those that fluoresced were transferred to tubes containing the same medium. All colonies were stored at $4^{\circ} \mathrm{C}$.

\section{Selection of potential isolates}

Four greenhouse assays were conducted under intermittent mist irrigation in a nursery located in Belo Oriente, Minas Gerais (Brazil) with a different group of isolates tested in each assay. The bacterial (107 isolates) were grown in 523 medium for $48 \mathrm{~h}$. Ten $\mathrm{ml}$ samples of bacterial suspensions at 0.2 optical density $(540 \mathrm{~nm})$, corresponding to about $10^{8} \mathrm{cfu} \mathrm{ml}^{-1}$, were placed in conical plastic tubes containing $55 \mathrm{ml}$ substrate composed of carbonized rice husk and vermiculite (1:1). The control contained substrate treated with $10 \mathrm{ml}$ sterilized water. The best root inducing isolate selected in assay 1 was used for comparison in the remaining assays. Cuttings of a commercial clone (Eucalyptus grandis hybrid), treated with an indole-butyric acid solution (IBA - $6000 \mu \mathrm{g} \mathrm{g}^{-1}$, routine of eucalyptus clonal propagation) (SIGMA, MO, USA) were planted and subsequently transferred to the greenhouse at $26-28^{\circ} \mathrm{C}$ under intermittent mist irrigation (relative humidity $\geq 80 \%$ ). After 35 days, the average rooting percentage and the root dry matter per rooted cutting were evaluated. A completely randomized block design was used with five replicates per treatment, where each plot consisted of ten cuttings.

\section{Identification of selected isolates}

DNA samples of the bacterial isolates were extracted as previously described (3). PCR of ribosomal 16S DNA (rDNA) was conducted using the bacterial genomic DNA as template.
Primer pair $\mathrm{p} 27 \mathrm{f}$ and $\mathrm{p} 152 \mathrm{r}$, homologous to the conserved regions of the bacterial rRNA $16 \mathrm{~S}$ gene, was used. The amplified fragments of $16 \mathrm{~S}$ rDNA were cloned in the pGEM-T vector (Promega), purified and sequenced in an automatic sequencer (ALFexpress, Pharmacia ${ }^{\circledR}$ ). M13 R and F primers were used for sequencing. Partial sequences of the 16S rDNA obtained were compared to $16 \mathrm{~S}$ rDNA sequences of organisms represented in the RDP data base ("Ribosomal Database Project", USA:http:/ /www.cme.msu.edu/RDP/html/index.html) and Genbank (http:/ /www.ncbi.nlm.nih.gov).

\section{Efficiency of isolates on the rooting of mini-cuttings}

The mini-cuttings root inducing efficiency of ten preselected isolates was tested for tree eucalyptus clones as previously described for cuttings, except that only $5 \mathrm{ml}$ of inoculum suspension were used per tube. A completely randomized block design was employed with 5 replicates per treatment in plots of 50 mini-cuttings. Rooting percentage and root dry matter were determined after 25 days in the greenhouse under intermittent mist irrigation at $26-28^{\circ} \mathrm{C}$.

\section{Indole-acetic acid (IAA) production}

In vitro IAA production was quantified using high performance liquid chromatography (HPLC) $(24,27)$.

The isolates were grown in Erlenmeyer flasks containing $200 \mathrm{ml}$ mineral medium supplemented with $0.5 \%$ glucose (SIGMA, MO, USA) and 0.02\% Ltryptophan (SIGMA, MO, USA) at $28^{\circ} \mathrm{C}$, in the dark. After $48 \mathrm{~h}$ of incubation, the growth medium was centrifuged at $2000 \mathrm{~g}$ for $20 \mathrm{~min}$ and the supernatant filtered through a $0.45 \mu \mathrm{m}$ Millipore filter. To avoid oxidation of indolic compounds, $0.05 \mathrm{~g}$ dithiotrheitol (SIGMA, MO, USA) was added to the filtrate. The $\mathrm{pH}$ of $15 \mathrm{ml}$ of the filtrate was adjusted to 2.7 and IAA was extracted 4 times with equal volumes of ethyl acetate (99.9\%) (SIGMA, MO, USA). Magnesium sulfate was added to remove excess water and the solution was filtered through qualitative filter paper. The acetate was evaporated under vacuum at $37^{\circ} \mathrm{C}$ and the dry residue was collected in 1.5 $\mathrm{ml}$ ethanol. This solution was frozen and stored in the dark until used for chromatographic analysis. The ethanol extract was filtered to remove impurities and subsequently injected onto a Licrosorb RP - 18 column $(10 \mu \mathrm{m})$. A solution of water: acetic acid: ethanol (84.2:0.8:15) was used as mobile phase, and peaks were detected with a UV detector at a wavelength of $280 \mathrm{~nm}$. After 20 min chromatography run, three reads per isolate were made.

\section{Mini-cuttings rooting induction by rhizobacteria versus IBA (Indole-butyric acid)}

In a preliminary test, isolate 3918 was selected as the most promising for in vitro IAA production. Thus, rooting of a hybrid clone in rhizobacterial treated substrate was compared with untreated and IBA treated mini-cuttings. The bacterial isolate 
was grown in 523 medium for $48 \mathrm{~h}$. A bacterial suspension of this isolate $\left(\mathrm{OD}_{540}=0.2 \mathrm{Abs} . \cong 10^{8}\right.$ c.f.u. $)$ was added to the rooting substrate at $0.1 \mathrm{ml} \mathrm{ml}^{-1}$ substrate. The substrate consisted of pine bark compost (Mecplant, PR, Brazil), carbonized rice husk, and vermiculite (30:20:50). Mini-cuttings of a hybrid $E$. grandis $\mathrm{x} E$. urophylla clone, containing two leaf half pairs, were planted in $55 \mathrm{ml}$ conical tubes with the treated substrate and immediately transferred to the greenhouse and maintained under intermittent mist irrigation. Untreated and IBA treated $\left(1000 \mu \mathrm{g} \mathrm{g}^{-1}\right)$ (SIGMA, MO, USA) mini-cuttings were planted in uninoculated substrate to serve as controls. Rooting percentage and root dry mass were evaluated after 20 days.

\section{RESULTS}

Forty-six (43\%) of the 107 isolates obtained were greenishyellow fluorescent colonies and the rest were obtained by the Bacillus sp. selective isolation method. Great variation in rooting rate and root dry matter was found among the 107 isolates tested. When compared to the control (substrate treated with sterilized water), ten isolates $(9.3 \%)$ were considered promising, based on the selection criterion of concomitant increase in rooting efficiency and root biomass. The best isolates (Isolate R98, code 3918 , Bacillus subtilis) presented a $219 \%$ increase in rooting frequency and a $223 \%$ increase in root biomass (Table 1).

The phylogenetic analysis of partial 16S rDNA sequences led to identification of eight isolates at the species level (Table 2). Of the ten pre-selected isolates, four belong to the genera Pseudomonas (MF2, MF4, Ca, FL2), and three belong to the specie Bacillus subtilis (S1, S2 e 3918), commonly reported as $\operatorname{PGPR}(8,21)$.

Increases in rooting percentage and root dry mass of minicuttings varied according to clone and rhizobacterial isolate tested. Rooting increased by $63 \%$ and root dry matter by $125 \%$ for the best isolate-clone combination, results considered highly promising for large scale vegetative propagation. Isolates MF4 (R87), FL2 (R29), CIIb (R13), FL1 (R73), MF2 (R10), Ca (R1) and S2 (R58) were the most efficient as rooting inducers of clone 1, and all isolates increased root dry matter over the control (Fig. 1). For the other two clones, all isolates increased rooting percentage over the control but differed with regard to root dry matter. Isolate MF4 produced the greatest root biomass increases in these two clones.

Only two of the ten isolates tested produced detectable amounts of IAA in vitro: isolate 3918 (Bacillus subtilis) produced $0.7 \mu \mathrm{g} \mathrm{ml}^{-1}$ and isolate MF4 (Pseudomonas sp.) produced $0.67 \mu \mathrm{g} \mathrm{ml}^{-1}$.

Rhizobacteria 3918 (Bacillus subtilis) addition to the substrate resulted in a significant increase in rooting and root biomass (Fig. 2) compared to the control and the IBA treatment. Gains were of 4.4 and $6.8 \%$ for rooting and of 82.4 and $106.7 \%$ for root biomass, respectively.

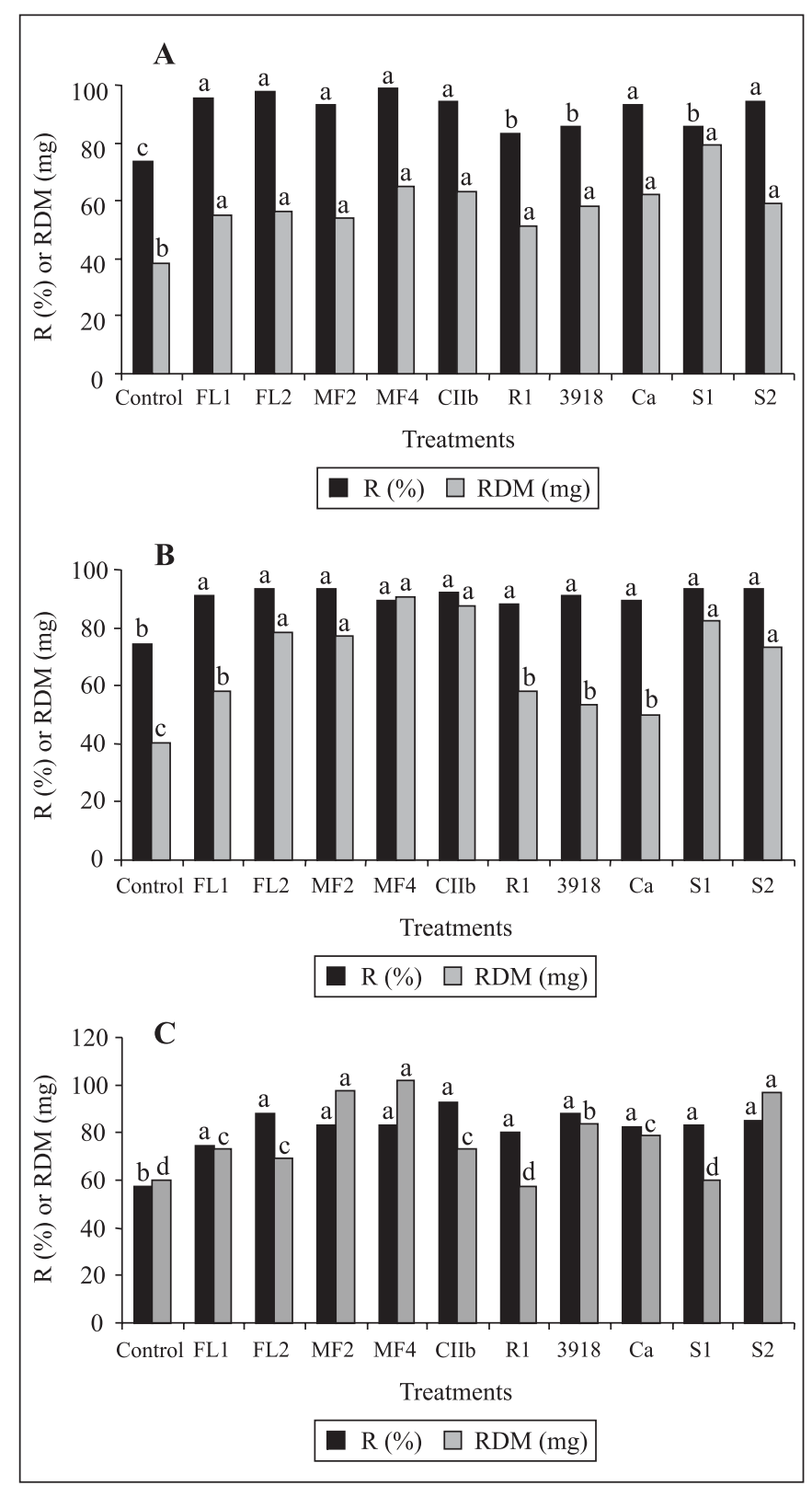

Figure 1. Rooting $(\mathrm{R})$ and root dry matter $(\mathrm{RDM})$ of rooted mini-cuttings of clones 1 (A), 2 (B), and 3 (C) inoculated with pre-selected rhizobacteria. Columns under the same letter and for the same variable do not differ statistically (Tukey, $\mathrm{p} \leq 0.05$ ).

\section{DISCUSSION}

The efficiency of rhizobacteria varied according to clone, propagation technique (macro or mini-cutting), and rhizobacterial isolate tested. $9.3 \%$ of the isolates tested were efficient in rhizogenesis induction and growth promotion, a much higher 
Table 1. Rooting $(\mathrm{R})$ and root dry matter (RDM) of rooted cuttings in substrate treated with rhizobacterial isolates.

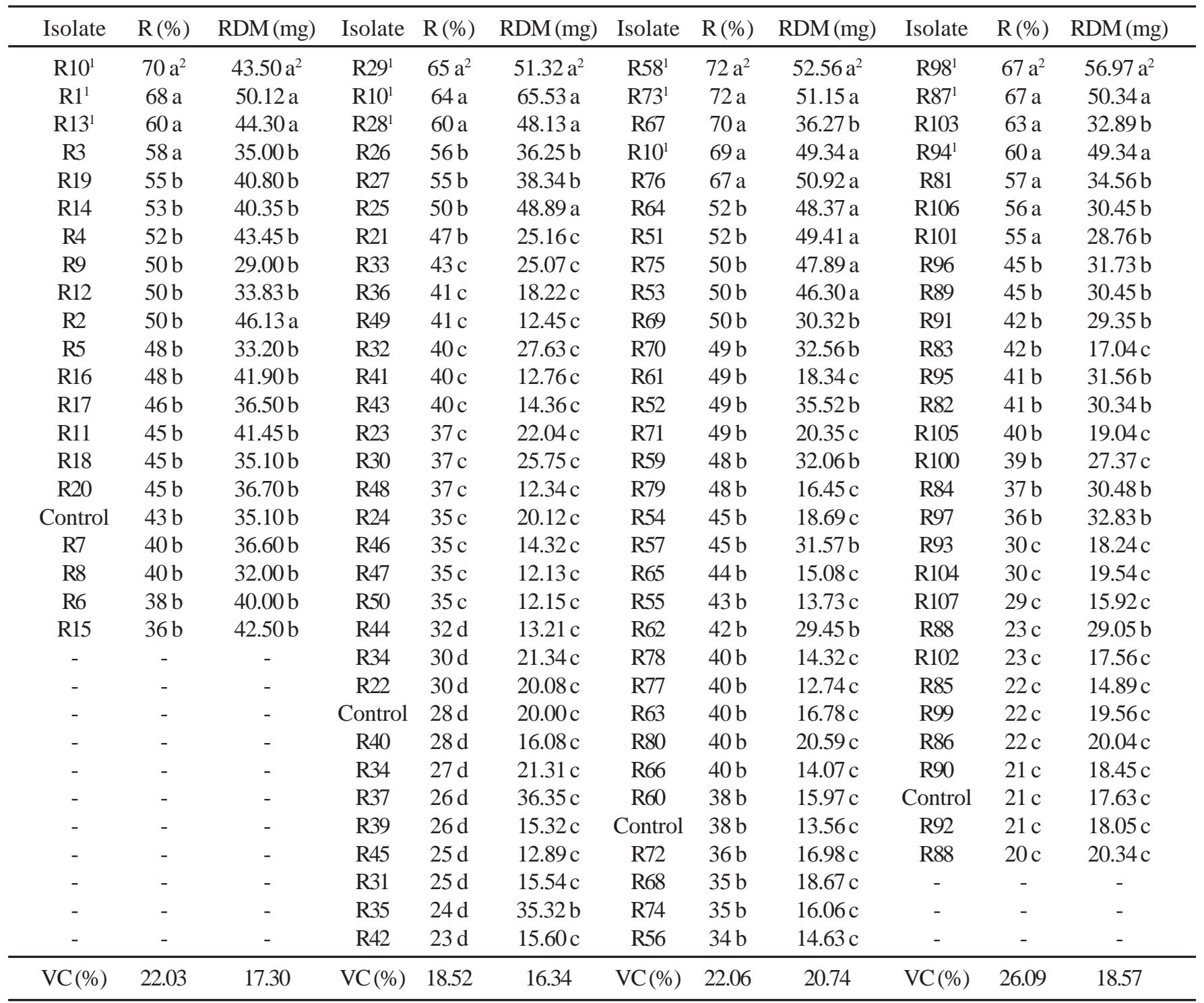

${ }^{1}$ Isolates selected for identification (Table 2); ${ }^{2}$ Treatments followed by the same letter do not differ significantly (Scott \& Knott, $\mathrm{p} \leq 0.05$ ).

percentage than the 1 to $5 \%$ observed in others crops $(5,20)$. This high frequency of PGPR induction of eucalyptus explained by the plant species itself, culture practices and the substrate used for rooting. In general, rooting substrates contain an organic fraction that favors growth of beneficial microorganisms (15). In tomatoes, addition of compost to the potting medium enhanced the frequency of PGPR and the humic fraction of the compost material was considered to positively affect development of soil microorganisms (2). An increase in numbers of bacteria and actinomycetes was observed in the rhizosphere of sweet bay (Laurus nobilis L.) plants grown in humic acid treated substrate (28).
There is apparently a certain specificity of PGPR isolates to the eucalypt clone employed. Isolates promoting growth in a plant species can be ineffective in others (25). Differences in quantity and quality of root exudates of different plant species, as well as of cultivars and genotypes of the same species have been reported $(4,5,26)$ and may explain a possible rhizobacterial isolate-clone specificity, but this must be confirmed in future studies.

Many microorganisms that interact with plants can synthesize hormones similar to those produced by the plant as growth regulator, such as auxins, gibberellins and cytocinins (22). Of these, auxin is one of the most well-known hormones 
Table 2. Molecular identification, based on homology (> 98\%) of the 16S rDNA, of rhizobacterial isolates selected as rooting promoters of eucalypt cuttings and mini-cuttings.

\begin{tabular}{|c|c|c|}
\hline Isolates & Codes & Identification \\
\hline R94 & R1 & Frauteria aurantia Swings et al., 1980 \\
\hline R73 & FL1 & Frauteria aurantia Swings et al., 1980 \\
\hline R 87 & MF4 & Pseudomonas sp. Migula 1894 \\
\hline $\mathrm{R} 10$ & MF2 & Pseudomonas sp. Migula 1894 \\
\hline $\mathrm{R} 1$ & $\mathrm{Ca}$ & Pseudomonas fulva Lizuga e Komagata 1963 \\
\hline $\mathrm{R} 29$ & FL2 & Pseudomonas aeruginosa (Schroeter, 1872) Migula 1900 \\
\hline R13 & $\mathrm{CIIb}$ & Stenotrophomonas maltophilia (Hugh 1981) Palleroni e Bradbury 1993/ S. Nitritireducens Finkmann et al., 2000 \\
\hline $\mathrm{R} 28$ & S1 & Bacillus subtilis Cohn 1872/ B. vallismortis Roberts et al., 1996 \\
\hline R58 & $\mathrm{S} 2$ & Bacillus subtilis Cohn 1872/ B. vallismortis Roberts et al., 1996 \\
\hline R98 & 3918 & Bacillus subtilis Cohn 1872/ B. vallismortis Roberts et al., 1996 \\
\hline
\end{tabular}

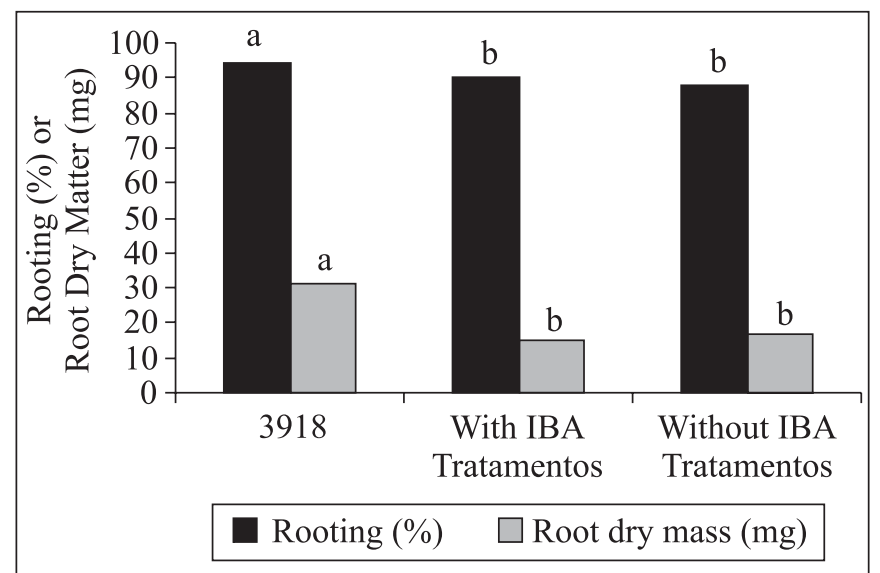

Figure 2. Rooting and root dry matter of mini-cuttings in substrate inoculated with rhizobacterial isolate 3918 (Bacillus subtilis) and of mini-cuttings with and without indole-butyric acid (IBA, $1000 \mu \mathrm{g} \mathrm{g}^{-1}$ ) treatment. Columns under the same letter and for the same variable differ statistically (Tukey, $\mathrm{p} \leq 0.05$ ).

because of its important roles in the initial processes of lateral and adventitious root formation (12) and root elongation (29). PGPR may produce auxin themselves and may also enhance plant synthesis of auxin (13). IAA is the most commonly produced auxin in nature, synthesized mainly through tryptophan dependent pathways. Several constitutive or induced pathways are known in rhizobacteria, mainly in the Pseudomonas spp., involving plasmidial or genomic DNA (14).

In contrast to our results, about $80 \%$ of the bacterial isolates present in soil are able to produce IAA (14). In the present work, only two isolates (20\%) produced IAA in vitro, and only in small concentrations (less than $1 \mu \mathrm{g} \mathrm{ml}^{-1}$ ). However, multiplication of the bacterial population in the rhizosphere and continued release of small quantities of IAA might enhance rhizogenesis. Furthermore, other indolic compounds, such as indole-pyruvic, indole-acetamide and indole-carboxylic-acid, can be involved in root formation (7).

The isolates selected in this study produced small amounts $\left(0.7 \mu \mathrm{g} \mathrm{ml}^{-1}\right)$ of IAA, appeared sufficient to enhance initiation of root formation and root elongation, since significant differences were detected for rooting percentage and root dry mass in cuttings and mini-cuttings treated with the bacterial isolates. Host plantdependent stimulus of rooting development of cuttings was observed in work carried with a mutant of $P$. fluorescens that produces a high amount of IAA (10). This indicates that the effect of IAA depends not only on the quantity produced by the bacteria, but also on the endogenous level of the hormone in the plant, which may vary according to plant genotype and age. Additionally, bacteria production IAA and this may be an important strategy to detoxify excess tryptophan released in the rhizosphere (17). Plant growth promoting isolates indirectly favor their own development, since they depend on the metabolites released to the rhizosphere by their hosts, increasing the quantity of exudates and the area of exudation (14).

The results obtained in this work show a potential for use of PGPR in the mass clonal propagation of eucalypts from cuttings or mini-cuttings. Selected rhizobacterial isolates can stimulate rhizogenesis and plant growth, maximizing yield of rooted cuttings in clonal nurseries.

\section{ACKNOWLEDGMENTS}

The authors would like to thank the following forest Industries Aracruz Celulose, CAF Santa Bárbara, Cenibra, Plantar, Cia. Suzano Bahia-Sul, Votoratin Celulose e Papel (VCP) and Veracel, for their logistic and financial support of part of this work. We are also indebted to Dr. Eli Lopes (Bio Soja Indústrias Químicas e Biológicas Ltda.) for critical review of the manuscript and CNPq, for a research fellowship granted to A.C. Alfenas. 


\section{RESUMO}

\section{Promoção do enraizamento e crescimento de eucalipto por Rizobactérias}

Neste trabalho, testaram-se 107 rizobactérias, isoladas da rizosfera de mudas de clones de eucalipto, quanto ao seu potencial como promotoras de enraizamento de estacas e miniestacas de eucalipto, em substrato à base de casca de arroz carbonizada e vermiculita (1:1). Estacas e miniestacas foram plantadas em tubetes cônicos contendo substrato tratado e não tratado (testemunha) e foram mantidas sob nebulização intermitente de água a $26-28^{\circ} \mathrm{C}$. Aos 35 dias, avaliou-se a porcentagem média de estacas enraizadas e a massa seca do sistema radicular. Dez isolados destacaram-se como indutores de enraizamento e crescimento, propiciando ganhos de até $110 \%$ e de $250 \%$, respectivamente. Esses isolados também foram eficientes no enraizamento de miniestacas, cujos ganhos variaram de acordo com o clone e isolado testado. Os maiores incrementos obtidos no enraizamento de estacas foram superiores aos observados para miniestacas. Em geral, quanto menor o índice de enraizamento do clone, maior foi o ganho médio obtido com a inoculação. Apenas os isolados 3918 (código R98) e MF4 (código R87) foram capazes de produzir ácido indol-acético (AIA) in vitro, em quantidades equivalentes a 0,7 e $0,67 \mu \mathrm{g} / \mathrm{ml}$ de suspensão, respectivamente. Quando comparados ao tratamento de miniestacas em ácido indol butírico (AIB), estes isolados promoveram incrementos significativos na porcentagem de enraizamento e na massa seca do sistema radicular de miniestacas.

Palavras chave: Eucalyptus, clonagem, miniestaquia, estaquia, rizobactéria

\section{REFERENCES}

1. Alfenas, A.C.; Zauza, E.A.V.; Mafia, R.G.; Assis, T.F. (2004). Clonagem e doenças do eucalipto. Editora UFV, Viçosa, 442p.

2. Alvarez, M.A.B.; Gagné, S.; Antoun, H. (1995). Effect of compost on rhizosphere microflora of the tomato and the incidence of plant growth promoting rhizobacteria. Appl. Environ. Microbiol., 61, 194199.

3. Ausubel, F.M.; Brent, R.; Kingston, R.E.; Moore, D.D.; Seidman, J.G.; Smith, J.A.; Struhl, K. (1999). Short Protocols in Molecular Biology. John Wiley and Sons Inc, New York, 1104p.

4. Baldani, V.L.D.; Dobereiner, J. (1980). Host plant specificity in the infection of cereals with Azospirillum spp. Soil Biol. Biochem., 12, 433-439.

5. Burr, T.J.; Caesar, A. (1984). Beneficial Plant Bacteria. Crit. Rev. Plant Sci., 2, 1-20.

6. Chanway, C.P. (1997). Inoculation of tree roots with PGPR soil bacteria: an emerging technology for reforestation. For. Sci., 43, 99-112.

7. Costacurta, A.; Vanderleyden, J. (1995). Synthesis of phytohormones by plant-associated bacteria. Crit. Rev. Microbiol., 21, 1-18.
8. Da Luz, W.C. (1996). Rizobactérias promotoras de crescimento de plantas e de bioproteção. Revisão Anual de Patologia de Plantas, 4, $1-50$.

9. Digat, B.; Expert, J.M.; Bossis, E. (1993). Ces bactèries qui protègent et stimulant lês semences et les plantules. PHM Rev. Hort., 341, 16-21.

10. Dubeikovsky A.N.; Mordukhova E.A.; Kochetkov, V.V.; Plodarpova, F.Y.; Boronin, A.M. (1993). Growth promotion of blackcurrant softwood cuttings by recombinant strain Pseudomonas fluorescens BSP53a synthesizing an increased amount of indole-3-acetic-acid. Soil Biol. Biochem., 25, 1277-1281.

11. Eneback, S.A.; Wei, G.; Kloepper, J.W. (1998). Effects of PGPR on loblolly and slash pine seedlings. For. Sci., 44, 139-144.

12. Gaspar, T.; Kevers, C.; Penel, C.; Greppin, H.; Reid, D.M.; Thorpe, T.A. (1996). Plant hormones and plant growth regulators in plant tissue culture. In vitro - Plant Cell. Dev. Biol., 32, 272-289.

13. Gaudin, V.; Vrain, T.; Jouanin, L. (1994). Bacterial genes modifying hormonal balances in plants. Plant Physiol. Biochem., 32, 11-28.

14. Glick, B.R.; Patten, C.L.; Holguin, G.; Penrose, D.M. (1999). Biochemical and genetics mechanisms used by PGPR. ICP, Ontario, 267p.

15. Hoitink, H.A.; Fahy, P.C. (1986). Basis for the control of soilborne plant pathogens with composts. Ann. Rev. Phytopathol., 24, 93-114

16. Kado, C.I.; Heskett, M.S. (1970). Selective media for isolation of Agrobaterium, Corynebacterium, Erwinia, Pseudomonas and Xanthomonas. Phythopathology, 60, 969-976.

17. Katsy, E.I. (1997). Participation of auxins in regulation of bacterial and plant gene expression. Russ. J. Genet., 33, 463-473.

18. King, E.O.; Ward, M.K.; Raney, D.E. (1954). Two simple media for the demonstration of pyocyanin and fluorescin. J. Lab. Clin. Med., 44, 301-307.

19. Kloepper, J.W.; Leong, J.; Teintze, M. (1980). Enhanced plant growth by siderophores produced by plant growth promoting rhizobacteria. Nature, 286, 885-886.

20. Kloepper, J.W.; Schroth, M.N. (1978). Plant growth promoting rhizobacteria on radishes. Proc 4th Int. Conf. Plant Path. Bact Angers., 879-882.

21. Mahaffe, W.F.; Kloepper, J.W. (1994). Applications of plant growth promoting rhizobacteria in sustainable agriculture. In: Pankhurst, C.E.; Doube, B.M.; Gupta, V.V.S.R.; Grace, P.R. (eds). Management in Sustainable farming systems. CSIRO, Australia, p.23-31.

22. Melo, I.S. (1998). Rizobactérias promotoras de crescimento de plantas: descrição e potencial de uso na agricultura. In: Melo, I.S.; Azevedo, J.L. (eds). Ecologia Microbiana. EMBRAPA Meio Ambiente, Jaguariúna, p.86-116.

23. Mohammad, G.; Prasad, R. (1998). Influence of microbial fertilizers on biomass accumulation in polypotted Eucalyptus calmadulensis seedlings. J. Trop. For., 4, 74-77.

24. Prikryl, Z.; Vancura, V.; Wurst, M. (1985). Auxin formation by rhizosphere bacteria as a factor of root growth. Biol. Plantarum., 27, 159-163.

25. Schroth, M.N.; Hancock, J. (1982). Disease suppressive soil and root colonizing bacteria. Science, 16, 1376.

26. Shishido, M.; Chanway, C.P. (1999). Spruce growth response specificity after treatment with plant growth promoting Pseudomonas. Can. J. Bot., 77, 22-31.

27. Srinivasan, M.; Petersen, D.J.; Holl, F.B. (1996). Influene of indoleacetic-acidproducing Bacillus isolates on the nodulation of Phaseolus vulgaris by Rhizobium etli under gnotobiotic conditions. Can. J. Microbiol., 42, 1006-1014.

28. Vallini, G.; Pera, A.; Valdrighi, M.; Giovannetti, M. (1993). Influence of humic acids on laurel growth, associated rhizospheric microorganisms and mycorrhizal fungi. Biol. Fert. Soils., 16, 1-4.

29. Yang, T.; Law, D.M.; Davies, P.J. (1993). Magnitude and kinetics of stem elongation induced by exogenous indole-3-acetic acid in intact light grown pea seedling. Plant Physiol., 102, 717-724. 